Therapeutics, Cardiorespiratory PT Practice, Musculoskeletal PT Practice, and Neurological PT Practice. The ways of transfer of Canadian experience to the national system of training of specialists in this field are considered.

Key words physical therapy, student, programs, vocational training, physiotherapy, multidisciplinary approach.

удк 37.017 .4

Тетяна Пахотіна

Сумський державний педагогічний університет імені А. С. Макаренка ORCID ID 0000-0002-5132-4326

DOI 10.24139/2312-5993/2020.02/285-292

\title{
ПАТРІОТИЧНЕ ВИХОВАННЯ ЯК ПРЕДМЕТ ПОРІВНЯЛЬНО-ПЕДАГОГІЧНИХ ДОСЛІДЖЕНЬ
}

у статmі з'ясовано сутність патріотичного виховання як предмету порівняльно-педагогічних досліджень. З'ясовано, що патріотизм являє собою моральну основу життездатності держави, важливий внутрішній мобілізуючий ресурс, що базується на активній громадянській позиції особистості, їі готовності самовіддано служити своїй Вітчизні. Патріотизм виявляється в практичній діяльності, спрямованій на всебічний розвиток своєї країни, захист ії інтересів. Виховання патріотизму є важливою складовою виховної діяльності школи.

Ключові слова: патріотизм, патріотичне виховання, порівняльно-педагогічні дослідження, Україна, Польща.

Постановка проблеми. Патріотизм як моральна цінність та сукупність соціально-політичних відносин є потужним фактором і необхідною умовою для захисту національних інтересів, відродження та зміцнення української нації. В умовах нинішньої економічної, соціальної, духовної та культурної кризи особливої актуальності набуває необхідність патріотичного виховання підростаючого покоління. Розвиток гострої конкуренції соціально-орієнтованих цінностей та гедоністичних ідеалів на рівні масової свідомості, неможливість повної реалізації потреб, нав'язаних мас-медіа, викликає зміни на духовному рівні, викривлення системи цінностей. Незбалансованість соціальних реформ призвела до розповсюдження в суспільстві таких негативних оціночних та поведінкових стереотипів, як громадянський інфантилізм, індивідуалізм та егоїзм, що, у свою чергу, спричинило падіння довіри до державних та правових інститутів. Одним із проявів кризової деформації свідомості $€$ ціннісний колапс, а особливої трансформації зазнають патріотичні почуття молодих людей. Необхідність цілеспрямованої державної політики у сфері національно-патріотичного виховання молоді зумовлена потребою консолідації всього українського суспільства для подолання викликів, що постали перед країною. За умов кризового стану соціуму та гострої конфліктної ситуації актуалізується необхідність дослідження ефективності реалізації державної політики у сфері національно-патріотичного виховання. 
Важливість патріотичного виховання задекларована в низці державних документів: Законах України «Про загальнодержавну підтримку молоді на 2004 - 2008 роки», «Про освіту», «Про загальну середню освіту»; низці концепцій: концепції національної системи виховання 1996 року, концепції національно-патріотичного виховання 2009 року, концепції Загальнодержавної цільової програми патріотичного виховання громадян на 2013-2017 роки, концепції громадянської освіти та виховання в Україні 2012 року; Указі Президента України «Про заходи щодо розвитку духовності, захисту моралі та формування здорового способу життя громадян», «Національній програмі патріотичного виховання громадян, формування здорового способу життя, розвитку духовності та зміцнення моральних засад суспільства» (1999), розпорядженні Президента України «Про заходи щодо подальшого вдосконалення системи патріотичного виховання молоді» (2001), Указі Президента України «Про Національну програму відродження та розвитку українського козацтва на 2000-2005 рр.», Указі Президента України «Про Концепцію допризовної підготовки та військово-патріотичного виховання молоді» (2002), Постанові Верховної Ради України «Про заходи Кабінету Міністрів України щодо захисту національних інтересів держави у сферах національно свідомого і патріотичного виховання молодого покоління та забезпечення умов його розвитку», розпорядженні Кабінету Міністрів України «Заходи щодо виконання у 2008 році Загальнодержавної програми підтримки молоді на 2004 - 2008 роки», розпорядженні Кабінету Міністрів України «Про схвалення Концепції Державної цільової національнокультурної програми розвитку Українського козацтва на 2009 - 2011 роки», Державних національних програмах «Освіта» («Україна XXI століття»), «Діти України», «Стратегії національно-патріотичного виховання дітей та молоді на 2016 - 2020 роки».

Аналіз актуальних досліджень. Зважаючи на свою актуальність, проблема патріотичного виховання дітей та молоді стала предметом досліджень таких вітчизняних та зарубіжних науковців, як Ю. Афанасьєва, О. Базилевська, Є.Барилко, В. Белан, Н. Вишнівська, В. Герасимчук, І. Дзюбенко, Г. Костюшко, К. Кузіна, П. Мазур, Е. Осевська, Л. Солярчик, А. Стєпнік, Ю. Толмачова та ін.

Незважаючи на значну кількість наукових публікацій з окресленої проблематики, серед дослідників відсутня одностайність щодо визначення понять «патріотизм» та «патріотичне виховання».

Мета дослідження - з'ясувати сутність патріотичного виховання як предмету порівняльно-педагогічних досліджень.

Методи дослідження: теоретичні: аналіз, синтез, порівняння та узагальнення, за допомогою яких було вивчено наукові джерела 3 проблеми дослідження; метод термінологічного аналізу, що уможливив з'ясувати сутність ключових понять дослідження. 
Виклад основного матеріалу. Незаперечним $€$ факт, що патріотизм це моральна основа життєздатності держави, важливий внутрішній мобілізуючий ресурс, що базується на активній громадянській позиції особистості, її готовності самовіддано служити своїй Вітчизні. Це моральний принцип, моральна норма та моральне почуття, що виникло ще на початку становлення людства та було глибоко осмислене вже античними теоретиками. Патріот - людина, яка виражає та реалізує у своїх учинках глибоке почуття поваги та любові до рідної країни, ії історії, культурних традицій та народу.

Особливого значення набувають культура, мистецтво, власне все те, що духовно звеличує людину. Існування культури без національного коріння, генетичної пам'яті, віками набутої духовної спадщини неможливе. Завжди традиційна народна культура в Україні відігравала роль національної. Наша країна багата традиціями, позаяк сьогодні питання збереження і відтворення їх украй актуальне (Базилевська, 2016, с. 59).

Патріотизм - це складне багатогранне явище. Будучи однією 3 найбільш важливих для людської спільноти цінностей, він поєднує в собі соціальні, політичні, духовні, культурні, історичні та багато інших компонентів, проявляючись, у першу чергу, емоційно-піднесеним ставленням до Батьківщини. Патріотизм $€$ важливою складовою духовного багатства особистості, що характеризує високий рівень їі соціальної свідомості.

Український педагогічний словник дає таке визначення патріотизму: це «одне з найглибших громадянських почуттів, змістом якого $є$ любов до батьківщини, відданість своєму народові, гордість за надбання національної культури. Патріотизм виявляється в практичній діяльності, спрямованій на всебічний розвиток своєї країни, захист їі інтересів. Виховання патріотизму - важлива складова виховної діяльності школи. У процесі вивчення різних навчальних предметів в учнів формуються патріотичні погляди і переконання» (Гончаренко, 1997, с. 249).

Патріотичне виховання спирається на такі загальнопедагогічні принципи виховання, як дитиноцентризм, природовідповідальність, культуровідповідальність, гуманізм, урахування вікових та індивідуальних особливостей. Водночас патріотичне виховання має власні принципи, а саме: принцип національної спрямованості; принцип самоактивності й саморегуляції; принцип полікультурності; принцип соціальної відповідності; принцип історичної і соціальної пам'яті; принцип міжпоколінної наступності (Концепція національно-патріотичного виховання дітей та молоді, с. 6).

Фактична відмова держави впродовж довгого часу від більш-менш послідовної політики патріотичного виховання, рухливість соціальної структури суспільства та відсутність його ціннісної єдності, сприяли деградації та занепаду інститутів соціалізації молоді та появі різного роду 
субкультур, екстремістських течій та угрупувань, віртуалізації дозвілля. У пошуку почуття безпеки та власної ідентичності молодь приєднується до доступних неформальних груп, що стають для неї інформаційними фільтрами, унаслідок чого знижується якість сприйняття цінностей та нормативних зразків, що транслюються через традиційні та формальні інститути, на які опирається держава в галузі патріотичного виховання.

Як слушно зауважує О. Барилко, за останні десятиліття, особливо в епоху науково-технічної революції, коли гуманітарна сфера життя людей зазнала нестримної комерціалізації внаслідок панування раціоналістичних ідей, прагматичного ставлення до життя (істинне те, що корисне), духовні цінності, до яких відноситься патріотизм, почали втрачати свою вартість. Засоби масової інформації заполонилися низькопробною продукцією, яка відволікає від реалій життя, налаштовує на аморальні дії, збуджує агресивність, провокує до антисоціальних вчинків. Поняття патріотизм, любов до Батьківщини, служіння народові фактично не зустрічаються на шпальтах сьогоденних часописів, або подаються в непривабливому, а то й гротескному вигляді. Девальвація духовних цінностей обернулася для України значними втратами в галузі економіки, культури, негативно позначилася на здоров'ї людей, призвела до скорочення народонаселення, поглиблення економічної кризи. Вихід зі скрутного становища, в якому опинилася наша держава, пов'язується з поновленням високого статусу відсторонених цінностей, в числі яких патріотизм посідає почесне місце (Барилко, 2011, с. 2).

Відновлення системи ціннісної регуляції суспільства має стати пріоритетним напрямом заходів, спрямованих на реанімацію патріотичного виховання в країні, оскільки в умовах високого ступеня соціальної дезінтеграції та деконсолідації, кризи довіри та соціальної справедливості істинний патріотизм сформувати неможливо. Молодь проводить у мережі інтернет більшу частину свого часу, не маючи при цьому надійного фундаменту ціннісних координат, які 6 відповідали не лише базовим цінностям українського суспільства, але й принципам його організації та функціонування в ньому соціальних відносин. Через це молодь легко піддається впливові 3MI, що не завжди сприятливо впливають на її поведінку та цінності. Тому на сьогодні можна констатувати, що 3MІ вже досить успішно конкурують з базовими агентами соціалізації, а сила впливу інтернету настільки велика, що навіть сім'я не в змозі протистояти негативному впливу його інформаційного середовища.

Молодь - майбутнє нашої держави, найважливіший фактор національної безпеки в стратегічному аспекті. І саме від сформованості у дітей і молоді національної свідомості та гідності, громадянськості, патріотичності, соціальної активності, фізичної та соціально-психологічної готовності стати на захист своєї Батьківщини залежить майбутнє України. У таких умовах цілком закономірно постає потреба пошуку ефективних вихов- 
них механізмів, які здатні забезпечити становлення та розвиток сучасної особистості - патріота, громадянина Української держави (Костюшко, 2016, с. 34).

$\mathrm{Ha}$ нашу думку, важливим у вирішенні означеного питання $\epsilon$ вивчення досвіду інших країн у галузі патріотичного виховання. Одним із найближчих наших сусідів $є$ Польща, що являє собою досить цікавий приклад, адже досягла вже значних результатів у розробці нових методів та підходів до виховання патріотизму в підростаючого покоління.

Патріотизм, на думку польської молоді, - це соціально-політичне почуття та форма ідеології, що поєднує в собі любов до своєї Батьківщини, відчуття соціального зв'язку та відданість своїй нації з повагою до інших націй та дотриманням їх суверенних прав. Але якщо в попередніх поколінь не було проблем із визначенням сутності патріотизму - готовність віддати своє життя на благо своєї країни, активна боротьба під час національних повстань чи на фронтах світових воєн, то зараз часи змінилися, а з ними і розуміння патріотизму набуло змін. Сьогоднішній патріотизм - це повага до державної символіки, польської мови, культури та історії. Це заохочення молоді до розумного ставлення до екології, розподілу побутових відходів, збереження лісів та рік у чистоті, економії води та електроенергії, активної участі в місцевих, національних та міжнародних ініціативах (Stec).

Найперша роль у формуванні патріотичних почуттів належить родині та школі, а ще великий внесок у розвиток дитини робить церква, тому в Польщі здійснюється активна співпраця з батьками та вчителями для забезпечення належного рівня патріотичного виховання дітей (Starzyńska-Rosiecka).

Кожна школа має на меті всебічний розвиток молоді, у тому числі шляхом формування почуття культурної та національної ідентичності, патріотичних поглядів, пробудження інтересу до культури регіону та місцевого життя. Працюючи з дітьми та молоддю, вчителі повинні формувати позитивне ставлення до людського життя, Батьківщини та природи. Батьки сподіваються, що школа забезпечить їм освіту та виховання з почуттям поваги до загальнолюдських цінностей. На жаль, останнім часом такі поняття, як патріотизм та патріотичне виховання втратили силу свого значення, вони стали банальними від частого використання для певних політичних цілей. Тому особливої ваги набуває роль учителя, який повинен докласти зусиль для навчання любові до Вітчизни.

Сучасний патріотизм - це не лише повага до національного минулого та традицій, це також турбота про політичну долю країни, а ще більше турбота про сім'ю, повага до приватної та суспільної власності, сумлінне виконання обов'язків на робочому місці.

Це не лише визнання незалежності та суверенітету країни, великих та знакових подій історії, але й формування універсальних установок, дотримання та повага до закону, соціальної дисципліни, сумлінне виконання обов'язків. Зрілий патріот - це людина, яка цікавиться минулим 
країни, ії культурними та економічними досягненнями, традиціями та цінностями. їй відомі біографії видатних співвітчизників, знакові дати історичних подій, вона поважає національні свята, їй не соромно польського громадянства та польської символіки, особливо за межами країни. Патріотичне виховання молоді також навчає їх поваги до державних символів, що проявляється в досить простих жестах - уважне прослуховування та спів гімну під час шкільних урочистостей, збереження серйозності та зосередженості під час святкування річниць національних свят, підняття національних прапорів під час цих свят.

Кожна країна досягає могутності передусім силою своїх окремих громадян. 3 цієї причини патріотизм означає турботу людини про свій особистий розвиток, фізичне здоров'я, а також про психічну, духовну та релігійну зрілість. Молоді патріоти самі вирішують свою долю, вибирають майбутнє своєї країни та нації, тому дуже важливо з дитинства прививати патріотичні погляди, відчуття відповідальності за долю держави.

Часто в повсякденному житті можна бачити прояви негативу, нечесності, корупції, політичних суперечок тощо. Це перешкоджає укоріненню патріотичних поглядів як у молоді, так і у старшого покоління, тому потрібно змінювати, але не самі цінності, а форму їх передачі, щоб громадяни не почували себе безпомічними, розгубленими і навіть байдужими. Потрібно уникати надмірної ідеалізації, разом шукати способи покращення, будівництва якіснішого світу, ніж той, у якому ми живемо. Треба не боятися помилок та не приховувати їх, адже для пізнання та усвідомлення своєї ідентичності окрім сфери загальних цінностей, традицій та досвіду, найважливіше - це когнітивна відкритість, яка дозволяє творчо поєднувати елементи історії з повсякденним життям та майбутнім (Adamiec).

Висновки та перспективи подальших наукових розвідок. Як бачимо, патріотичне виховання $€$ актуальним для Польщі так само, як і для України. Маючи близьке територіальне, мовне, історичне сусідство, ми маємо багато спільного, тому не зайвим, на нашу думку, буде цікавитись досвідом у вихованні та переймати позитивні здобутки, яких у польського народу вже чимало. Сміливість у визнанні помилок, рішучість, турбота про духовний та моральний стан суспільства, про майбутнє країни - ось лише деякі аспекти, що стали результатом серйозних наукових розробок. Тому перспективами подальших наукових розвідок $є$ імплементація позитивних концептуальних ідей польського досвіду в практику патріотичного виховання в Україні.

\section{ЛУТЕРАТУРА}

Базилевська, О. (2016). Формування громадянської культури та національної свідомості в учнів з особливими освітніми потребами шляхом упровадження петриківського розпису в позаурочній роботі. Особлива дитина: навчання і виховання, 2, 59-66 (Basylevska, O. Forming of civil culture and national consciousness for students with special educational needs by introduction petrykivka painting as folk art. Special child: teaching and upbringing, 2, 59-66). 
Барилко, Є. О. (2011). Виховання патріотизму в учнів середніх шкіл США (автореф. дис. канд. пед. наук: 13.00.07) (Barylko, Ye. O. (2011). Upbringing of patriotism in pupils of secondary schools of the USA (PhD thesis).

Гончаренко, С. (1997). Український педагогічний словник. Київ: Либідь (Honcharenko, S. (1997). Ukrainian Pedagogical Dictionary. Kyiv: Lybid).

Концепція національно-патріотичного виховання дітей та молоді: Додаток до Наказу Міністерства освіти і науки України від 16. 06. 2015 № 641 (The concept of national-patriotic upbringing of children and youth: Supplement to the Order of the $M$ inistry of Education and Science of Ukraine of 16.06.2015 № 641).

Костюшко, Г. (2016). Національно-патріотичне виховання молоді в контексті етнопедагогічних засад. Науковий часопис Начіонального педагогічного університету імені М. П. Драгоманова. Серія 11. Соціальна робота. Сочіальна педагогіка. Вип. 21, 33-39 (Kostiushko, G. National-patriotic education of youth in the context of ethno-pedagogical principles. Scientific journal of M. P. Drahomanov National Pedagogical University. Series 11. Social work. Social pedagogy. No. 21, 33-39).

Adamiec, A. Patriotyzm we współczesnej szkole. URL: http://www.edukacja.edux.pl/p-950patriotyzm-we-wspolczesnej-szkole.php

Stec, J. Edukacja patriotyczna. Dobre praktyki. URL: https://www.monitorszkoly.pl/artykul/edukacja-patriotyczna-dobre-praktyki.

Starzyńska-Rosiecka, D. MEN: 80 proc. nauczycieli historii deklaruje kształtowanie postaw patriotycznych. URL: https://dzieje.pl/edukacja/men-80-proc-nauczycieli-historiideklaruje-ksztaltowanie-postaw-patriotycznych

\section{PEЗЮME}

Пахотина Татьяна. Патриотическое воспитание как предмет сравнительнопедагогических исследований.

В статье выяснена сущность патриотического воспитания как предмета сравнительно-педагогических исследований. Выяснено, что патриотизм представляет собой нравственную основу жизнеспособности государства, важный внутренний мобилизующий ресурс, основанный на активной гражданской позиции личности, ее готовности самоотверженно служить своему Отечеству. Патриотизм проявляется в практической деятельности, направленной на всестороннее развитие своей страны, защиту ее интересов. Воспитание патриотизма является важной составляющей воспитательной деятельности школы.

Ключевые слова: патриотизм, патриотическое воспитание, сравнительнопедагогические исследования, Украина, Польша.

\section{SUMMARY}

PakhotinaTetiana Patriotic education as a subject of comparative-pedagogical studies.

The essence of patriotic education as a subject of comparative-pedagogical studies is clarified in the article. It has been found out that patriotism is the moral basis of the vitality of the state, an important internal mobilizing resource, based on the active civic position of the individual, his/her willingness to serve his/her Motherland. Patriotism is manifested in practical activities aimed at comprehensive development of one's country, protection of its interests. Upbringing of patriotism is an important component of the educational activities of the school.

Patriotism, according to the Polish youth, is a socio-political feeling and a form of ideology that combines love for their homeland, a sense of social connection and commitment to their nation with respect for other nations and respect for their sovereign rights. But if in previous generations there were no problems with defining the essence of patriotism - the willingness to give up their lives for the good of their country, active struggle during national uprisings or at the fronts of world wars, now times have changed, and with 
them the understanding of patriotism has changed. Today's patriotism is a respect for state symbols, Polish culture and history. Patriotism also envisages encouraging young people to be sensible about the environment, to distribute household waste, to keep forests clean, to save water and electricity, to participate in local, national and international initiatives actively.

It is concluded that patriotic education is as relevant to Poland as it is to Ukraine. Having a close territorial, linguistic, historical neighborhood, we have a lot in common, so it is necessary to study Polish experience in patriotic education and to adopt positive achievements that Polish people already have. Courage in admitting mistakes, determination, caring for the spiritual and moral state of society, the future of the country - these are just some of the aspects that have resulted from serious scientific developments. The prospects for further scientific exploration lie in implementation of positive conceptual ideas of the Polish experience in the practice of patriotic education in Ukraine

Key words: patriotism, patriotic education, comparative-pedagogical studies, Ukraine, Poland.

удк 377:327.7єС

Юрій Христій

Сумський державний педагогічний університет імені А.С. Макаренка ORCID ID 0000-0003-1051-9378

DOI 10.24139/2312-5993/2020.02/292-301

\section{КОНЦЕПТУАЛЬНІ ЗАСАДИ МІЖНАРОДНОГО СПІВРОБІТНИЦТВА У СФЕРІ ПРОФЕСІЙНО-ТЕХНІЧНОÏ ОСВІТИ В ЄВРОПЕЙСЬКОМУ СОЮЗІ}

У статті обгрунтовано концептуальні засади міжнародного співробітництва у сфері профресійно-технічної освіти в Європейському Союзі. Схарактеризовано напрями міжнародного співробітництва у срері професійно-технічної освіти, зокрема: розвиток, координація та/або реалізація міжнародної політики у сфері ПТО; підвищення інституційного потенціалу державних органів влади/надання технічної допомоги, у тому числі й щодо розроблення стандартів ПтО та кваліфрікаційних систем; розвиток та управління міжнародними мережами закладів Пто (обмін інформацією та спільні проекти); сертифрікачія й забезпечення якості надання освітніх послуг у сфері ПТО за кордоном; маркетинг провайдерів ПТО та розвиток бізнесу; розвиток програм мобільності; розвиток наукових досліджень, обмін інформацією та мережування; розробка систем навчання, курикулуму й навчального обладнання.

Ключові слова: міжнародне співробітництво, профресійно-технічна освіта, Європейський Союз.

Постановка проблеми. В умовах інтеграції України до європейського освітнього простору актуалізується проблема реформування всіх ланок освітньої системи на засадах міжнародного співробітництва, зокрема й професійно-технічної освіти. Необхідність дотримання означеної стратегії задекларована в низці державних документів, а саме: «Державній цільовій програмі розвитку професійно-технічної освіти на 2011-2015 роки», «Національній стратегії розвитку освіти в Україні на 2012-2021 рр.», «Стратегії державної кадрової політики на 2012-2020рр.», що містять положення щодо міжнародного співробітництва. На необхідності міжнародного співробітництва у сфері професійно-технічної освіти 